\title{
Pengaruh Penatalaksanaan Inisisasi Menyusu Dini Terhadap Onset Pengeluaran Kolostrum di Surabaya
}

\author{
Nur Masruroh \\ Universitas Nahdlatul Ulama Surabaya, masruroh@unusa.ac.id \\ Ratna Ariesta Dwi Andriani \\ Universitas Nahdlatul Ulama Surabaya, ratnariesta@unusa.ac.id
}

\begin{abstract}
Abstrak
Inisisasi menyusu dini (IMD) adalah memberikan ASI segera setelah bayi dilahirkan dalam waktu 30-60 menit setelah bayi dilahirkan. Inisiasi Menyusu Dini juga dengan jelas telah tercantum dalam Buku Acuan Asuhan Persalinan (APN) dari Departemen Kesehatan Republik Indonesia sehingga harus dilaksanakan oleh seluruh bidan. Kolostrum mulai diproduksi oleh tubuh saat kehamilan, dan keluar pada awal seorang ibu akan menyusui. Tujuan dari penelitian ini adalah untuk mengetahui pengaruh penatalaksanaan inisiasi menyusu dini terhadap onset pengeluaran kolostrum ibu. Metode penelitian yang digunakan adalah cross sectional dengan sampel ibu bersalin primipara yang melahirkan di BPM Istiqomah dan BPM Bashori selama bulan Maret-Juli 2018 berjumlah 60 orang. Teknik pengambilan sampel pada penelitian ini menggunakan teknik accidental sampling dengan kriteria inklusi : ibu primipara, melahirkan spontan pervaginam tanpa penyulit dan bersedia menjadi responden. Analisis data menggunakan t tes mendapatkan hasil bahwa pelaksanaan inisiasi menyusu dini berpengaruh terhadap onset pengeluaran kolostrum dengan $p=0,03$ $(<0,05)$. Lama pelaksanaan inisiasi menyusu dini berpengaruh terhadap onset pengeluaran kolostrum dengan $\mathrm{p}=0,01(<0,05)$. Bidan sebagai ujung tombak kesehatan ibu dan anak meningkatkan sosialisasi pentingnya inisiasi menyusu dini sejak periode kehamilan
\end{abstract}

Kata kunci : IMD, onset, kolostrum

\begin{abstract}
Abstrack
The initiation of early breastfeeding is giving breast milk as soon as the baby is born within 30-60 minutes after the baby is born. Initiation of Early Breastfeeding is also clearly stated in the Maternity Care Reference Book of the Ministry of Health of the Republic of Indonesia so that it must be carried out by all midwives. Colostrum begins to be produced by the body during pregnancy, and comes out at the beginning of a mother's breastfeeding. The purpose of this study was to determine the effect of management of early breastfeeding initiation on the onset of maternal colostrum expenditure. The research method used was cross-sectional with samples of primiparous mothers giving birth at BPM Istiqomah and BPM Bashori during the months of March-July 2018 totaling 60 people. Data analysis using t test found that the implementation of early breastfeeding initiation had an effect on the onset of colostrum expenditure with $\mathrm{p}=0.03(<0.05)$. The duration of initiation of early breastfeeding has an effect on the onset of expenditure of colostrum with $p=0.01(<0.05)$. Midwives as the spearhead of maternal and child health increase the socialization of the importance of early breastfeeding initiation since the pregnancy period
\end{abstract}

Keywords: early breasfeeding, onset, colostrum

\section{PENDAHULUAN}

Inisisasi menyusu dini (IMD) adalah

memberikan ASI segera setelah bayi dilahirkan, dalam waktu 30 - 60 menit setelah bayi dilahirkan. Tujuan IMD diantaranya adalah: kontak kulit dengan 
kulit membuat bayi lebih tenang, saat IMD bayi menelan bakteri baik dari kulit ibu yang akan membentuk koloni di kulit dan usus bayi sebagai perlindungan diri, kontak kulit dengan kulit antara bayi dan ibu akan meningkatkan ikatan kasih sayang ibu dan bayi, mengurangi perdarahan setelah melahirkan serta mengurangi terjadianya anemia (Kemenkes RI, 2014).

Hasil Riskesdas 2018 menunjukkan bahwa ibu yang melakukan Inisisasi Menyusu Dini (IMD) mengalami kenaikan dari $34,5 \%$ menjadi $58,2 \%$. Sedangkan ibu yang melaksanakan IMD kurang dari 1 jam adalah 84,1\% dan lebih dari 1 jam sebanyak 15,9\%, lebih tinggi dibandingkan pada tahun 2013 yaitu 11,7\%. Pemerintah mentargetkan IMD untuk tahun 2019 adalah 50\% sehingga pada tahun 2018 ini target tersebut sudah tercapai (Riskesdas 2018).

Kolostrum merupakan cairan yang pertama kali disekresi oleh kelenjar payudara, mengandung tissue debris dan residual material yang terdapat dalam alveoli dan duktus dari kelenjar payudara sebelum dan setelah masa puerperium. Kolostrum merupakan cairan dengan viskositas kental, lengket dan berwarna kekuningan. Kolostrum mengandung tinggi protein, mineral, garam, vitamin $\mathrm{A}$, nitrogen, sel darah putih dan antibodi yang tinggi daripada ASI matur. Selain itu, kolostrum masih mengandung rendah lemak dan laktosa (Nugroho, 2011).

Hasil penelitian Dewey pada 2011 menyatakan bahwa $24 \%$ dari ibu yang mengalami stres saat kehamilan dan persalinan, mengalami keterlambatan keluarnya kolostrum (>72 jam pasca persalinan). Faktor lain yang ikut berpengaruh terhadap lambatnya keluar kolostrum adalah: cara persalinan, lamanya persalinan, sakit yang dialami saat persalinan, dan keletihan setelah persalinan. Faktor lain yang juga mempengaruhi keluarnya kolostrum adalah status gizi ibu, perawatan payudara, isapan bayi segera setelah lahir serta obesitas pada ibu.

Kolostrum mulai diproduksi oleh tubuh saat kehamilan, dan keluar pada awal seorang ibu akan menyusui. Kolostrum adalah makanan yang terbaik bagi bayi, memenuhi kebutuhan nutrisi bayi baru lahir, berwarna kuning, rendah lemak, tapi tinggi akan kandungan karbohidrat, protein dan terutama kandungan antibodi. Pengeluaran kolostrum pada ibu bersalin secara spontan adalah minimum adalah 0,42 jam dan maksimum 30,83 jam (Fikawati, 2013).

Tujuan penelitian ini adalah untuk mengetahui pengaruh penatalaksanaan IMD terhadap onset pengeluaran kolostrum pada ibu bersalin di Surabaya. 


\section{METODE}

Penelitian ini menggunakan metode cross sectional. Populasi dalam penelitian ini adalah semua ibu yang melahirkan di BPM Istiqomah dan BPM Bashori pada bulan Maret-Juli 2018. Sedangkan sampelnya adalah sebagian ibu yang melahirkan di BPM Istiqomah dan BPM Bashori bulan Maret-Juli 2018 sebanyak 60 orang. Teknik pengambilan sampel pada penelitian ini menggunakan teknik accidental sampling dengan kriteria inklusi: ibu primipara, melahirkan spontan pervaginam tanpa penyulit dan bersedia menjadi responden.

Pengambilan data dilakukan dengan observasi pelaksanaan IMD serta observasi onset pengeluaran kolostrum, kemudian data dianalisis menggunakan $\mathrm{T}$ test berpasangan.

\section{HASIL PENELITIAN}

Pengumpulan data didapatkan 60 responden. Keseluruhan responden adalah ibu bersalin primipara, persalinan spontan pervaginam dan tanpa komplikasi

Tabel 1.1 Karakteristik responden berdasarkan usia di Surabaya

\begin{tabular}{lll}
\hline Usia & Frekuensi & \\
& $\mathrm{n}$ & $\%$ \\
\hline$<20$ th & 19 & 31,6 \\
$20-35$ th & 26 & 43,4 \\
$>35$ th & 15 & 25 \\
Jumlah & 60 & 100
\end{tabular}

Sumber : data primer April 2018

Berdasarkan tabel 1.1 diatas terlihat bahwa hampir setengah $(43,3 \%)$ dari ibu bersalin berada di rentang usia 20-35 tahun.

Tabel 1.2 Karakteristik responden berdasarkan tingkat pendidikan di Surabaya

\begin{tabular}{lcc}
\hline Pendidikan & Frekuensi & \\
\hline & $\mathrm{n}$ & $\%$ \\
\hline SMP & 13 & 21,6 \\
SMA & 30 & 50 \\
PT & 17 & 28,4 \\
Jumlah & 60 & 100 \\
\hline
\end{tabular}

Sumber : data primer April 2018

Berdasarkan tabel diatas dapat dilihat bahwa setengah (50\%) dari responden memiliki pendidikan terakhir di jenajng SMA

Tabel 1.3 Analisis Pengaruh Penata laksanaan IMD Terhadap Onset Pengeluaran Kolostrum di Surabaya

\begin{tabular}{lcccc}
\hline Variabel & Frekuensi & $\begin{array}{c}\text { Onset } \\
\text { pengeluaran } \\
\text { kolostrum }\end{array}$ & $\begin{array}{c}\mathrm{p} \\
\text { (value) }\end{array}$ \\
& \multicolumn{5}{c}{$\begin{array}{c}\text { Mean } \\
\text { (jam) }\end{array}$} & $<0,05$ \\
\cline { 2 - 5 } & $\mathrm{n}$ & $\%$ & & \\
\hline $\begin{array}{l}\text { Penatalaksanaan IMD: } \\
\text { Pelaksanaan IMD: }\end{array}$ & 55 & 91,6 & 10,4 & 0,03 \\
Ya & 5 & 8,4 & 13,2 & \\
Tidak & & & & 0,01 \\
$\begin{array}{l}\text { Lama IMD : } \\
<1 \text { jam }\end{array}$ & 35 & 58,3 & 12,8 & \\
$>1$ jam & 25 & 41,7 & 11,2 & \\
& & & &
\end{tabular}

\section{PEMBAHASAN}

\section{Pengaruh pelaksanaan IMD terhadap onset pengeluaran kolostrum}

Onset pengeluaran kolostrum lebih cepat pada responden yang melakukan Inisiasi Menyusu Dini dengan rerata 10,4 jam sedangkan pada responden yang tidak melakukan Inisiasi Menyusu Dini memiliki rerata onset pengeluaran kolostrum 13, 2 jam. Hasil analisis penghitungan menggunakan $\mathrm{T}$ test 
independent didapatkan hasil $\mathrm{p}=0,03$ $(<0,05)$ yang berarti dapat disimpulkan bahwa pelaksanaan insisiasi menyusu dini berpengaruh terhadap onset pengeluaran kolostrum.tersebut, penelitian dari Mawarti dan Mayasari di tahun 2014 menyatakan bahwa $64 \%$ ibu yang melakukan Inisiasi Menyusu Dini (IMD) onset laktasi nya berada pada kurun waktu $<12$ jam.

Onset pengeluaran kolostrum dipengaruhi antara lain oleh status gizi ibu, terlihat dari penelitian yang dilakukan oleh Hajerah di tahun 2015 menunjukkan bahwa $69 \%$ ibu yang memiliki status gizi baik atau IMT normal, onset pengeluaran kolostrumnya adalah <12 jam. Menurut hasil penelitian dari Nurjanah di tahun 2015, diketahui bahwa ibu yang melakukan Inisiasi Menyusu Dini sebagian besar atau $77,5 \%$ onset pengeluaran kolostrumnya lebih cepat $(<12$ jam $)$.

\section{Pengaruh lama IMD terhadap onset pengeluaran kolostrum}

Responden yang melakukan inisiasi menyusu dini $>1$ jam rerata onset pengeluaran kolostrumnya adalah 11,2 Hasil analisis menggunakan $t$ test independent mendapatkan hasil 0,01 $(>0,05)$ yang artinya lama pelaksanaan inisiasi menyusu dini berpengaruh terhadap onset pengeluaran kolostrum.
Hasil Riskesdas 2018 menunjukkan bahwa di Indonesia pelaksanaan inisiasi menyusu dini $>1$ jam masih sangat rendah yaitu hanya $15,9 \%$ dari target pemerintah yang 50\%. Hasil penelitian Mohamad dkk di tahun 2015 menyatakan bahwa dukungan dari petugas kesehatan berpengaruh terhadap keberhasilan pelaksanaan Inisiasi Menyusu Dini.

\section{SIMPULAN}

Simpulan dari hasil penelitian ini adalah pelaksanaan inisiasi menyusi dini berpengaruh terhadap onset pengeluaran kolostrum. Lama inisiasi menyusu dini berpengaruh terhadap onset pengeluaran kolostrum. Bidan sebagai ujung tombak kesehatan ibu dan anak meningkatkan sosialisasi pentingnya inisiasi menyusu dini sejak periode kehamilan

\section{REFERENSI}

Adam W, 2015, Pengaruh Penatalaksanaan Inisiasi Menyusu Dini Terhadap Waktu Pengeluaran ASI di RSUD Prof Dr H Aloei Saboe Kota Gorontalo, Jurnal Poltekes Gorontalo

Fikawati S, 2010, Kajian Implementasi dan Kebijakan ASI Eksklusif dan Inisiasi Menyusu Dini di Indonesia, Makara Kesehatan vol 14 no 1 hal 17-24

Kemenkes RI, 2014, Situasi dan Analisis ASI Eksklusif, Pusat Data dan Informasi Kementrian Kesehatan, Jakarta 
Mohamad S dkk, 2015, Faktor faktor yang berhubungan dengan Pemberian Inisiasi Menyusu Dini Oleh Bidan Di RS Prof dr Aloei Saboe Gorontalo, JIKMU vol 5 no 2 a hal 390-396

Rahayu RD dkk, 2012, Keberhasilan Inisiasi Menyusu Dini (IMD) dan Lama Pemberian ASI, Jurnal Terpadu Ilmu Kesehatan jilid 1 hal 129-132

Riskesdas, 2018, Kementerian Kesehatan Republik Indonesia, Badan Penelitian dan Pengembangan Kesehatan

Susan Yanti, 2015, Pelaksanaan Inisiasi Menyusu Dini di RSUD Sumedang, Jurnal Bidan "Midwife Journal" volume 1 no 2 . 